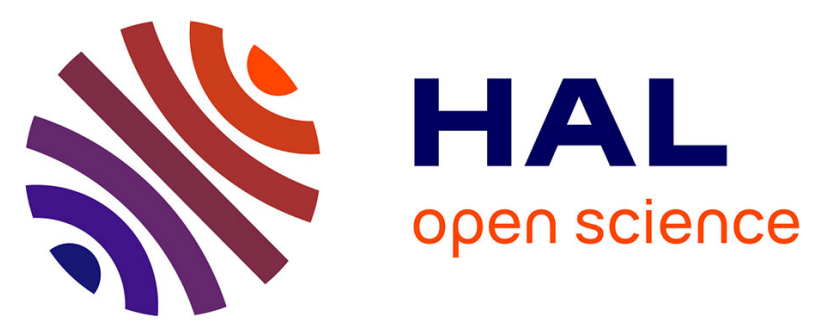

\title{
Composition, texture and methane potential of cellulosic residues from Lewis acids organosolv pulping of wheat straw
}

\author{
Sandra Constant, Abdellatif Barakat, Mike Robitzer, Francesco Di Renzo, \\ Claire Dumas, Françoise Quignard
}

\section{To cite this version:}

Sandra Constant, Abdellatif Barakat, Mike Robitzer, Francesco Di Renzo, Claire Dumas, et al.. Composition, texture and methane potential of cellulosic residues from Lewis acids organosolv pulping of wheat straw. Bioresource Technology, 2016, 216, pp.737-743. 10.1016/j.biortech.2016.06.019 . hal01330682

\section{HAL Id: hal-01330682 \\ https://hal.science/hal-01330682}

Submitted on 28 May 2020

HAL is a multi-disciplinary open access archive for the deposit and dissemination of scientific research documents, whether they are published or not. The documents may come from teaching and research institutions in France or abroad, or from public or private research centers.
L'archive ouverte pluridisciplinaire $\mathbf{H A L}$, est destinée au dépôt et à la diffusion de documents scientifiques de niveau recherche, publiés ou non, émanant des établissements d'enseignement et de recherche français ou étrangers, des laboratoires publics ou privés. 


\section{Accepted Manuscript}

Composition, texture and methane potential of cellulosic residues from Lewis acids organosolv pulping of wheat straw

Sandra Constant, Abdellatif Barakat, Mike Robitzer, Francesco Di Renzo, Claire Dumas, Françoise Quignard

PII: S0960-8524(16)30819-7

DOI: http://dx.doi.org/10.1016/j.biortech.2016.06.019

Reference: BITE 16641

To appear in:

Bioresource Technology

Received Date:

10 April 2016

Revised Date:

3 June 2016

Accepted Date:

4 June 2016

Please cite this article as: Constant, S., Barakat, A., Robitzer, M., Renzo, F.D., Dumas, C., Quignard, F., Composition, texture and methane potential of cellulosic residues from Lewis acids organosolv pulping of wheat straw, Bioresource Technology (2016), doi: http://dx.doi.org/10.1016/j.biortech.2016.06.019

This is a PDF file of an unedited manuscript that has been accepted for publication. As a service to our customers we are providing this early version of the manuscript. The manuscript will undergo copyediting, typesetting, and review of the resulting proof before it is published in its final form. Please note that during the production process errors may be discovered which could affect the content, and all legal disclaimers that apply to the journal pertain. 


\title{
Composition, texture and methane potential of cellulosic
}

\section{residues from Lewis acids organosolv pulping of wheat straw}

Sandra Constant ${ }^{\mathrm{a}}$, Abdellatif Barakat ${ }^{\mathrm{b}}$, Mike Robitzer ${ }^{\mathrm{a}}$, Francesco Di Renzo ${ }^{\mathrm{a}, *}$, Claire Dumas $^{\mathrm{c}}$, and Françoise Quignard ${ }^{\mathrm{a}}$

aCGM, UMR 5253 CNRS-Université de Montpellier-ENSCM, Matériaux Avancés pour la Catalyse et la Santé, 8 Rue de l'Ecole Normale, 34296 Montpellier Cedex 5, France. Fax: +33 (0)4 6716 3470; Tel: +33 (0)4 6716 3460; E-mail: direnzo@enscm.fr ${ }^{\mathrm{b}}$ INRA, UMR 1208, Ingénierie des Agropolymères et Technologies Emergentes (IATE) 2, Place Pierre Viala, 34060 Montpellier Cedex 1, France; E-mail: barakat@supagro.inra.fr.

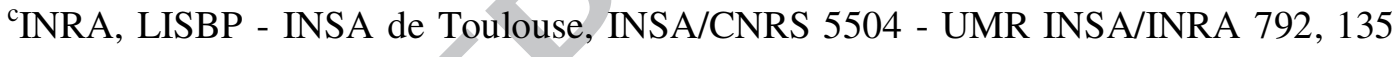
avenue de Rangueil, 31077 Toulouse Cedex 04, France. Fax: +33 (0)5 61559760 ; Tel: +33 (0)5 6155 9401; E-mail: cl_dumas@insa-toulouse.fr

\begin{abstract}
Cellulosic pulps have been successfully isolated from wheat straw through a Lewis acids organosolv treatment. The use of Lewis acids with different hardness produced pulps with different delignification degrees. The cellulosic residue was characterised by chemical composition, X-ray diffraction, FT-IR spectroscopy, $\mathrm{N}_{2}$ physisorption, scanning electron microscopy and potential for anaerobic digestibility. Surface area and pore volume increased with the hardness of the Lewis acid, in correspondence with the
\end{abstract}


decrease of the amount of lignin and hemicellulose in the pulp. The non linearity of the correlation between porosity and composition suggests that an agglomeration of cellulose fibrils occurs in the early stages of pulping. All organosolv pulps presented a significantly higher methane potential than the parent straw. A methane evolution of $295 \mathrm{Ncm}^{3} / \mathrm{g}$ OM was reached by a moderate improvement of the accessibility of the native straw.

\section{Keywords}

homogeneous catalysis; ethanosolv; biomass valorisation; surface area; epidermal structure; biodegradability

\section{Introduction}

With the increase in world population and decline in oil resources, the main global techno-economic challenges are the development of durable sources of energy and materials. Lignocellulosic biomass is a good candidate for this purpose since it is a renewable carbon source present in large amounts all around the world in less competition with food resources than the crops used to produce first generation biofuels. The challenge for the exploitation of second-generation lignocellulosic biomasses is the disruption of their more complex structure, formed of interconnected cellulose, hemicelluloses and lignin. So far, a large number of pre-treatment methods and biorefinery processes have been proposed to separate the components, especially to allow the valorisation of cellulose, the easiest-digestible component (Fang, 2013). Regarding cellulosic part, pre-treatments of lignocellulosic biomass in enzymatic or chemical conditions are conducted to improve the reactivity of the material for 
bioethanol, biobutanol or methane conversion (Hendriks and Zeeman, 2009; Monlau et al., 2013; Barakat et al., 2014). Typically, the main objective of pre-treatment processes is to increase cellulose and hemicelluloses accessibility to chemicals or microorganisms (bacteria, enzymes) (Arantes and Sadddler, 2011; Motte et al., 2014). Chemical composition, cellulose crystallinity, surface area and pore size are the major factors affecting accessibility and biodegradability of the materials (Monlau et al., 2013). The exploitation of natural resources has to cope with the natural variability of the biomass sources. In order to deal with this variability, several types of processes have been developed: mechanical, physical, mechano-chemical and chemical ones (Monlau et al., 2013; Barakat et al., 2013).

The valorisation of all components of lignocellulosic biomass is a potential major asset of second generation biorefineries (Hayes, 2009). Among chemical treatments, organosolv pulping is a classical process to isolate every component of the biomass material (Kleinert and Tayenthal, 1932). In this process, biomass is treated with an aqueous-organic solvent mixture (e.g. acetic or formic acid, methanol, ethanol or acetone) at high temperature with or without the presence of a catalyst (acid or base) (Pan et al., 2005). This pretreatment conduces to hemicellulose degradation, lignin solubilisation and creates cellulosic pulp.

An important asset of the organosolv process is the possibility of tailoring catalyst and conditions in order to produce lignin with potentially valuable properties (Lawter et al., 1996; Lora and Glasser, 2002). In organosolv processes based on easily recoverable alcohol solvents, several catalysts have been investigated as $\mathrm{HCl}, \mathrm{H}_{2} \mathrm{SO}_{4}$, and recently some Lewis acids. Inorganic salt as $\mathrm{FeCl}_{2}$ and $\mathrm{FeCl}_{3}$ have been studied as catalyst for the hemicellulose separation in corn stover and have shown a significant efficiency (Liu 
et al., 2009). Huijgen et al. (2011) investigated the catalytic effect of $\mathrm{H}_{2} \mathrm{SO}_{4}, \mathrm{HCl}$ and $\mathrm{MgCl}_{2}$-assisted organosolv treatment on willow wood and wheat straw. $\mathrm{MgCl}_{2}$ seemed to more selectively improve delignification of willow wood. Kim et al. (2010) have shown that using $\mathrm{FeCl}_{3}$ during organosolv process allows an effective hemicellulose dissolution and enhanced the enzymatic digestibility of barley straw (89\% enzymatic digestibility). The effectiveness of $\mathrm{FeCl}_{3}$ was also demonstrated on others biomass sources, e.g. poplar wood (Wang et al., 2013), olive tree (Lopez-Linares et al,, 2013) and sunflower stalks (Monlau et al., 2012). $\mathrm{AlCl}_{3}$ has been studied for the hemicellulose conversion from corn stover. $85.1 \%$ of hemicellulose conversion was reached after a hydrothermal treatment at $140^{\circ} \mathrm{C}$ (Yi et al., 2013).

Some catalysed organosolv processes are mainly oriented to the elaboration of lignins with specific properties (Constant et al., 2015) and cellulosic pulps are co-products of the process. In this paper, five Lewis acids with different hardness have been investigated as organosolv catalysts taking sulphuric acid as a reference acid. Characterisation of pulp residues in term of chemical and physical structure and anaerobic biodegradability have been used to estimate the effectiveness of the organosolv pretreatment and the possible valorisation of the pulp coproduct.

\section{Materials and Methods}

\subsection{Materials}

The wheat straw (WS) used in this study came from a single stock of soft wheat (Triticum Aestivum) harvested in Southern France. The composition of the native WS was cellulose $44.3 \%$, hemicelluloses $24.5 \%$, lignin $22.3 \%$, proteins $3.1 \%$, and ashes 
$3.4 \%$. The WS was dried at room temperature on site and subjected to a succession of knife mill grindings, first with a $5 \mathrm{~cm}$ grid, then with a $6 \mathrm{~mm}$ grid. Copper, ferrous and ferric chlorides, scandium triflate (trifluoromethylsulfonate, OTf), sulfuric acid and ethanol were purchased from Sigma-Aldrich. Gallium triflate was purchased from Strem.

\subsection{Pulping and fractionation of wheat straw (WS)}

The process was conducted as previously described (Constant et al., 2015). In typical experiments, $40 \mathrm{~g}$ of WS was mixed with $1.25 \mathrm{~L}$ of aqueous ethanol $\left(\mathrm{EtOH} 65 \%, \mathrm{H}_{2} \mathrm{O}\right.$ $35 \%$ ) with $8 \mathrm{mmol} \mathrm{L}^{-1}$ Lewis acid (or $4.4 \mathrm{mmol} \mathrm{L}^{-1} \mathrm{H}_{2} \mathrm{SO}_{4}$ ) in a $2 \mathrm{~L}$ autoclave during 2 hours at $160^{\circ} \mathrm{C}$. The pulp was recovered by filtration and washed with aqueous ethanol. Lignin was afterwards precipitated and the remaining liquor was exploited for oligosaccharides and phenolic oligomers. Values of $\mathrm{pH}$ have been measured and found to be in the range $2.0-2.5$ for the initial batch and 2.4-3.2 at the end of the extraction.

\subsection{Characterisation of wheat straw fractions}

Throughout this study, the results will be reported in increasing order of cation hardness according to the Pearson model: $\mathrm{FeCl}_{2}<\mathrm{CuCl}_{2}<\mathrm{FeCl}_{3}<\mathrm{Ga}(\mathrm{OTf})_{3}<\mathrm{Sc}(\mathrm{OTf})_{3}$ (Constant et al., 2015). In order to have a complete overview of the pulp properties, seyen different characterisation methods were used. The carbohydrates and lignin composition of the extracted lignin and pulp residues were measured using a classical Klason method (Renard et al., 1997). An ash correction was applied. The crystallinity indexes (\% CrI) were determined using a Bruker D8 Advance X-ray equipment (Barakat et al., 2014). Nitrogen adsorption-desorption were performed on a 
micromeritics ASAP 2010 volumetric apparatus at $-196^{\circ} \mathrm{C}$. Before adsorption measurements, samples (30-50 mg) were outgassed at $40^{\circ} \mathrm{C}$ under vacuum during 72 hours. The specific surface area of WS pulping residues was evaluated using the BET method and the average pore size by the equivalent diameter Gurvitch method. The mesopore size distribution was calculated by the DFT method and pore volume was calculated from the adsorbed amount at $\mathrm{P} / \mathrm{P}^{\circ} 0.97$ by assuming a liquid nitrogen mass volume $0.81 \mathrm{~g} \mathrm{~cm}^{-3}$.

FTIR spectroscopy provided information on the chemical structure of different WS pulping residues. The FTIR spectra were recorded with a Nicolet 6700 FTIR spectrometer equipped with an ATR diamond single reflection crystal. All spectra were collected in absorbance in the $4000-700 \mathrm{~cm}^{-1}$ range.

Metal content in pulps were measured by inductively coupled plasma optical spectroscopy after mineralisation in acid medium at CNRS Central Analysis Service in Solaize (France). Scanning electron microscopy (SEM) pictures were recorded on a Hitachi S-4800 microscope after platinum metallisation. Double staining with safranin/fast green was used to show the presence of different components of the residues (Chang et al., 2009). Pulp residues were observed with an optical microscope at 3400 magnifications.

\subsection{Anaerobic biodegradability and methane production}

Anaerobic digestion experiments to measure the biodegradabilities were carried by the protocol of Jard et al. (2012). Samples were prepared in triplicate in $500 \mathrm{~mL}$ plasma bottles. Each bottle contained $2 \mathrm{~g} \mathrm{OM}$ (organic matter) of inoculum and $1 \mathrm{~g} \mathrm{OM}$ of ground wheat straw. Bottles were filled to $400 \mathrm{~mL}$ with a bicarbonate buffer 
complemented with nutrients.Biogas composition $\left(\mathrm{CH}_{4}, \mathrm{CO}_{2}, \mathrm{H}_{2}\right.$ and $\left.\mathrm{N}_{2}\right)$ was analysed using gas chromatography. Methane yields were calculated by dividing the corrected methane volume (standard pressure and temperature) by the $\mathrm{OM}$ weight of sample added to each bottle.

\section{Results and discussion}

\subsection{Yield and chemical composition of pulping residues}

The yield and the chemical composition of the cellulosic residue resulting from WS pulping with the different catalysts are reported in Table 1. The cellulosic residues were composed by $85-95 \%$ of saccharide derivatives and 5-15\% of lignin. The pulping yield varies from $55 \%$ for the less hard Lewis acid to $31 \%$ for the hardest one. The pulping yield of the benchmark treatment with $\mathrm{H}_{2} \mathrm{SO}_{4}(38 \%)$ was intermediate between these values.

\section{Table 1}

The fraction of each component of the parent straw which has been left in the pulping residue is reported in Fig. 1 as a function of the hardness of the metal cation of the Lewis acid. As a general trend, the yield of every component decreased with the hardness of the Lewis acid, witnessing a more severe disruption of the original lignocellulosic structure. Nevertheless, each component presented a more specific reactivity. As expected in a pulping treatment, the cellulose yield was always higher than the yields of hemicellulose and lignin. More specifically, the yield of lignin steadily decreased from $35 \%$ for the less hard cations to $13 \%$ for the hardest cations. 
The reference treatment with $\mathrm{H}_{2} \mathrm{SO}_{4}$ induced a delignification slightly better than the hardest Lewis acid treatments, just $9 \%$ of the lignin of parent straw being still present in the residue.

\section{Figure 1}

$46 \%$ hemicelluloses were retained in the residue for the softest Lewis acid $\left(\mathrm{FeCl}_{2}\right)$ and only $3 \%$ for harder $\mathrm{Ga}(\mathrm{OTf})_{3}$, the benchmark treatment with $\mathrm{H}_{2} \mathrm{SO}_{4}$ yielding an intermediate value of $14 \%$. However, the extraction of polysaccharides with $\mathrm{CuCl}_{2}$ showed an extremely selective catalytic behaviour. Indeed, with this relatively soft Lewis acid, just $9 \%$ of the original hemicelluloses remained in the residues with a remarkable cellulose yield (96\%). This cellulose yield was the highest observed, well above the yield obtained with softer and harder Lewis acid or the yield of $69 \%$ obtained with $\mathrm{H}_{2} \mathrm{SO}_{4}$. A high delignification rate in oxidative alkaline pulping was already observed with homogeneous copper catalysts (Rovio et al., 2012). In general, the Lewis acid pulping conduced to an extensive WS delignification and hemicellulose degradation. To our best knowledge, only few similar strong decreases in lignin and hemicelluloses content were previously reported in the ethanosolv literature. An ethanol-based organosolv fractionation of WS in harshest conditions $\left(190^{\circ} \mathrm{C}\right.$ with $30 \mathrm{mmol} \mathrm{L}^{-1} \mathrm{H}_{2} \mathrm{SO}_{4}$ ) conduced to $75 \%$ of delignification and $95 \%$ of xylan removal (Wildschut et al., 2013). The use of a still higher concentration of $\mathrm{H}_{2} \mathrm{SO}_{4}\left(0.5 \mathrm{~mol} \mathrm{~L}{ }^{-1}\right)$ at a lower temperature $\left(75^{\circ} \mathrm{C}\right)$ (Sun et al., 2000$)$ led to lower pulping yield $(66 \%)$ with higher hemicellulose $(21 \%)$ and lignin $(12 \%)$ contents than our reference $\mathrm{H}_{2} \mathrm{SO}_{4}$ treatment. Kim et al. (2010) claimed a removal of 100\% xylose and a low $40 \%$ 
cellulose yield after a $\mathrm{FeCl}_{3}$ ethanosolv process on barley straw in slightly harsher conditions than ours $\left(10 \mathrm{mmol} \mathrm{L}{ }^{-1}\right.$ metal salt, $\left.170{ }^{\circ} \mathrm{C}\right)$.

Beside fractionation, the process also allowed to solubilise part of the cellulose component. Indeed, the pulp yield decreases with the strength of the Lewis acid (see Table 1). Pulping with harder Lewis acids was able to disrupt also the most stable cellulosic fraction (see Fig. 1). The organosolv liquor was analysed by GCMS and contained some glucose-derived products as furfuraldehyde, hydroxymethylfurfural (HMF) and furan-2,5-dicarbaldehyde (Constant et al., 2015). The formation of HMF and furfural was also observed by Kim et al. in $\mathrm{FeCl}_{3}$ ethanosolv treatment (Kim et al., 2010). They showed that these compounds, often indicated as digestibility inhibitors, did not inhibit the pulp fermentation.

After pulping, the cellulosic residues contained a fraction of the residual metal from the Lewis acids (Table 1). The highest percentage amount was measured in the $\mathrm{FeCl}_{2}$ residue, the other residues contained less than $0.25 \mathrm{wt} \%$ of the Lewis acid metal. This residual metal can result from a complexation of the oxophilic metal with hydroxyl functions of cellulose and hemicelluloses. The assessment of the influence of metal content on the biodegradability of the residues is a significant result of this work.

\subsection{Chemical structure of the residues}

The chemical structure of the residue was characterised by analysing the infrared spectroscopy bands of specific chemical bonds and the X-ray diffraction percentage of cellulose crystallinity.

In the region of C-H stretchings (Fig. S2), the sharp bands at 2920 and $2851 \mathrm{~cm}^{-1}$, corresponding to the asymmetric and symmetric $\mathrm{C}-\mathrm{H}$ stretching of the lignin methoxy 
groups, disappeared after organosolv pulping. The broader bands of the $\mathrm{C}-\mathrm{H}$ stretching vibrations of carbohydrates evolved with the severity of the Lewis acid treatment. The band at $2890 \mathrm{~cm}^{-1}$ became more intense than the band at $2930 \mathrm{~cm}^{-1}$, an effect which can be attributed to the decrease of the hemicellulose fraction in the holocellulose mix. In all organosolv pulps, the typical aromatic $\mathrm{C}-\mathrm{H}$ in-plane deformation bands of lignin near 1120 and $1030 \mathrm{~cm}^{-1}$ are lumped with more intense cellulose bands. Nevertheless, a strong decrease of the absorbance of other typical lignin vibrations, such as the bands of carbonyl groups at $1730 \mathrm{~cm}^{-1}$ and phenolic $\mathrm{OH}$ around $1240 \mathrm{~cm}^{-1}$, is well correlated with the severity of the organosolv pulping.

Quantitative correlations between IR spectra and composition of lignocellulosic fractions have been proposed but their field of validity is often limited by the complexity of systems in which not only the ratio between components but also the properies of each component can vary. For instance, the ratios between the aromatic $\mathrm{C}=\mathrm{C}$ stretching at $1515 \mathrm{~cm}^{-1}$ and either the primary alcohol $\mathrm{O}-\mathrm{H}$ bending at $1430 \mathrm{~cm}^{-1}$ (Monlau et al., 2012) or the secondary alcohol O-H bending at $1317 \mathrm{~cm}^{-1}$ (Dang et al., 2007) have been proposed as indexes of the amount of lignin fraction. These absorbance ratios, reported in Table 2, had a 0.5 value in the initial straw (lignin/holocellulose ratio 0.32 from chemical analysis) and decreased to 0.3 or 0.25 after $\mathrm{CuCl}_{2}$ and $\mathrm{FeCl}_{2}$ treatments (lignin/holocellulose ratio 0.17). The residues of the hardest pulpings showed a zero value for both indexes, despite the lignin/holocellulose ratios from chemical analysis were $0.06-0.11$. It is likely that modifications underwent by the residual lignin in the pulping treatment accounted for the early disappearance of the band at $1515 \mathrm{~cm}^{-1}$. The $\mathrm{C}=\mathrm{C}$ stretching of aromatics is extremely sensitive to the nature and position of the substituent groups. A decrease of electron-donor and an increase of electron-acceptor 
groups, as well as a decrease of connectivity of lignin groups, could easily justify a red shift of the $\mathrm{C}=\mathrm{C}$ stretching which would be merged with the $\mathrm{OH}$ bendings around 1460 $\mathrm{cm}^{-1}$. In a similar way, the band at $1597 \mathrm{~cm}^{-1}$, also related to vibrations of aromatic $\mathrm{C}=\mathrm{C}$ bonds, presented a reduced intensity in residues related to the least hard Lewis acids $\left(\mathrm{CuCl}_{2}\right.$ and $\left.\mathrm{FeCl}_{2}\right)$ and was not observed at all in the residues from pulping with $\mathrm{H}_{2} \mathrm{SO}_{4}$ and the hardest Lewis acids.

\section{Table 2}

The modification of properties of the residual lignin was also evidenced by the disappearance of the band at $1658 \mathrm{~cm}^{-1}$, corresponding to carbonyls conjugated to aromatic rings, which was present in native straw and disappeared in all residues. The spectral region $1000-1100 \mathrm{~cm}^{-1}$ was especially complex, as it included several nearly superposed bands of $\mathrm{C}-\mathrm{C}$ and $\mathrm{C}-\mathrm{O}$ stretching, $\mathrm{C}=\mathrm{O}$ and $\mathrm{C}-\mathrm{H}$ bendings and collective ring vibrations. However, a clear pattern could be observed: with the decrease of the lignin amount in the residues treated with $\mathrm{H}_{2} \mathrm{SO}_{4}$ or the hardest Lewis acids, the aromatic C-H bending component around $1035 \mathrm{~cm}^{-1}$ decreased and the spectra assumed the two-pronged shape corresponding to the bending vibrations of the primary and secondary $\mathrm{OH}$ of cellulose.

The percentages of cellulose crystallinity in the residues were determined by XRD and are given in Table 2 . The parent straw had a crystallinity of 54\%. After pulping, the crystallinity indexes were between 46 and 58\%. In most cases, the organosolv pulping led to a lower crystallinity. An increase of 3-4\% of the crystallinity index was observed using $\mathrm{FeCl}_{3}$ and $\mathrm{Ga}(\mathrm{OTf})_{3}$ as catalyst. Wang et al. (2013) reported a similar increase for 
cellulosic residues from a poplar hydrothermal treatment at $160^{\circ} \mathrm{C}$ with $\mathrm{FeCl}_{3}$. The authors attributed this crystallinity increase to the removal of amorphous components from the biomass.

\subsection{Textural properties}

The textural properties of the residues were determined by nitrogen physisorption and by microscope imaging. The pore size distributions of parent straw and residues are shown in Fig. 2. Surface area, pore volume and average pore diameter are reported in Table 2. The initial straw had a very low surface area near $1 \mathrm{~m}^{2} \mathrm{~g}^{-1}$ and was a very compact material with virtually no mesopore volume. The organosolv treatment improved the material porosity. When $\mathrm{H}_{2} \mathrm{SO}_{4}$ was used, a surface area of $14 \mathrm{~m}^{2} \mathrm{~g}^{-1}$ and a pore volume of $0.018 \mathrm{~cm}^{3} \mathrm{~g}^{-1}$ were obtained. In the case of Lewis acid-catalyzed organosolv treatments, the resulting porosity was correlated to the hardness of the Lewis acid. The less hard Lewis acid produced residues with a porosity intermediate between raw straw and $\mathrm{H}_{2} \mathrm{SO}_{4}$-treated residue, whereas the hardest Lewis acids lead to residues more porous than $\mathrm{H}_{2} \mathrm{SO}_{4}$-treated residue. Surface area reached $28 \mathrm{~m}^{2} \mathrm{~g}^{-1}$ and pore volume reached $0.032 \mathrm{~cm}^{3} \mathrm{~g}^{-1}$ in the $\mathrm{Ga}(\mathrm{OTf})_{3}$-treated residue.

In some publications the porosity data are expressed as the volume of adsorbed $\mathrm{N}_{2}$ gas at standard temperature and pressure. It is worth to remember that throughout this paper the pore volume was expressed as the volume of $\mathrm{N}_{2}$ condensed in the mesopores, assumed having the liquid $\mathrm{N}_{2}$ density, a value more directly representative of the true pore volume.

\section{Figure 2}


The mesopore size distribution of all samples was quite broad, suggesting that the pores correspond to a variety of typologies. The average pore size for all samples was between 4.5 and $6.5 \mathrm{~nm}$ (Table 2). No correlation was found between the pore size values, the sample composition or the catalyst type. Comparable porosity values were obtained on rice straw acid-treated at $180{ }^{\circ} \mathrm{C}$, with surface area $11 \mathrm{~m}^{2} \mathrm{~g}^{-1}$ and pore volume $0.02 \mathrm{~cm}^{3} \mathrm{~g}^{-1}$ measured by Yu et al. (2009). Their pore size distribution presented a continuous distribution between 5 and $12 \mathrm{~nm}$ pore diameter.

For the accessibility of enzymes, the pore size of the residues is also important (Monlau et al., 2013). The smallest pore size accessible to enzymes (specifically cellulase from Trichoderma reesei) was set by Grethlein (1985) at $5 \mathrm{~nm}$. This suggests that about half the pore volume of our samples can contribute to improved enzyme accessibility. Furthermore, the average pore diameter in the parent straw was higher than $5 \mathrm{~nm}$, but the pore volume was so low that no significant effect on enzyme accessibility can be expected.

The porosity data would be expected to be correlated to residue composition, as the porosity is developed by the extraction of the lignin and hemicellulose matrix which lays between the cellulose fibrils. In Fig. 3, surface area and pore volume are reported as a function of the fraction of removed non-cellulosic matrix (fractions of lignin and hemicellulose in native straw minus their fractions in the pulp normalised on the fractions in native straw). The evolutions of surface area and pore volume were clearly correlated. Both of them steadily increase with the extraction of lignin and hemicellulose. 


\section{Figure 3}

The increase of porosity was nearly linear with the extracted amounts up to the extraction of about $70 \%$ of the initial matrix. The pace of pore volume opening became much steeper beyond the extraction of $70 \%$ of the non-cellulosic matrix. It is interesting to compare the measured porosity with the onewhich should be expected if the extraction of the matrix do not implied any shrinkage of the material. Lignin and hemicellulose represent around half the volume of the dry matter of native straw (see Table 1). By assuming a density of dry matter $1.5 \mathrm{~g} \mathrm{~cm}^{-3}$, the extraction of the noncellulosic matrix would correspond to the opening of a pore volume of $0.33 \mathrm{~cm}^{3} \mathrm{~g}^{-1}$ if the material retained its initial overall volume.

The slope of the increase of porosity below $70 \%$ extraction would correspond to the opening of $0.02 \mathrm{~cm}^{3} \mathrm{~g}^{-1}$ of mesopore volume if the whole non-cellulosic matrix were extracted at this pace. This formation of pore volume is one order of magnitude less steep than the one expected if the volume of extracted lignin and hemicellulose were completely recovered as pore volume. The more logical explanation of such a low increase of mesopore volume is that the matrix dissolution has induced a coalescence of cellulose fibrils, which have filled the volume left free by the pulping treatment with an overall shrinkage of the material.

Beyond $70 \%$ extraction, the slope of the increase of porosity would correspond to the opening of $0.28 \mathrm{~cm}^{3} \mathrm{~g}^{-1}$ of mesopore volume if the whole non-cellulosic matrix were extracted. This value is in good agreement with the volume left free from the amount of dissolved lignin and hemicellulose. Such a trend can be accounted for by assuming that, 
beyond a given agglomeration level, the cellulose fibrils have formed a stable tangle and undergo no further compaction when more non-cellulosic matrix is extracted.

The micrographs of wheat straw and cellulosic residues showed that residues had a microscopic morphology clearly different from the initial straw. The starting material had a compact structure composed by long and well-organised cellulosic fibres. In the case of residues, fibres seem to be shorter and randomly intersected. At higher magnification, “zip" structures can be observed in residues. These structures correspond to undissolved epidermal cells of wheat straw (Liu et al., 2005). In our study, it seems that the linkages between the cellulose fibrils were dissolved by the pulping and epidermal part was not totally fractionated. Lewis acids may dissolve hemicelluloses and separate cellulose fibrils. Epidermal cell structures are already well known in the literature of straw anatomy. The part of epidermal structure in Triticum aestivum wheat straw is estimated to around $24 \%$ by Singh et al. (2011). Because of the dense layers of epidermal cells, these structures are the most difficult part of straw to be fractionated (Sun, 2010). With the hardest Lewis acid the fibrils size were smaller and epidermal structures, albeit still observable, were less well defined.

With stained residues, it was possible to observe lignified tissues and cellulose distribution in the residues. Safranin stains lignified tissues in red, and fast blue stains both lignified and non-lignified cell walls in blue. Consequently, lignified tissues were red mixed with varying degrees of blue while essentially cellulosic cell wall layers, were blue. As presented previously, the native wheat straw has a compact structure composed of lignin and cellulose and any clear distribution of these two components can be distinguished on the stained WS. However, a trend can be observed among the stained residues. After $\mathrm{FeCl}_{2}$ and $\mathrm{CuCl}_{2}$ pulping, the fibrils were still composed of 
lignin and cellulose. With a hardest Lewis acid, as $\mathrm{Ga}(\mathrm{OTf})_{3}$, the residue was only stained in blue which means that no lignin was present in the material.

Lewis acid treatment has proven to be an effective way of increasing the porosity and fractionation of wheat straw. $\mathrm{Ga}(\mathrm{OTf})_{3}$ conduced to a very high surface area $\left(28 \mathrm{~m}^{2} \mathrm{~g}^{-1}\right)$. The epidermal structures were modified after treatment and still present in the residue material. Pore size (between 3 and $6 \mathrm{~nm}$ ) could enable a good accessibility of enzyme or bacteria to cellulosic content of residues.

\subsection{Biodegradability of residues}

The anaerobic degradability of the cellulosic residues was estimated through the production of biogas and specifically methane. The biogas route was chosen instead of the enzymatic cellulose hydrolysis as a simpler one-step biological process without any additional costs related to the enzyme addition or the hemicellulose separation..

The Lewis acids organosolv pulping residues were digested with anaerobic inoculum and the methane production was monitored. The lignin fraction of lignocellulosic biomass is recalcitrant to biological degradation. Considering that only the cellulosic and hemicellulosic parts of the pulp could be transformed during anaerobic digestion process, the most significant biodegradability index is the amount of methane produced per mass of polysaccharidic moiety. This ratio was $259 \mathrm{Ncm}^{3} \mathrm{CH}_{4} / \mathrm{g}$ (holocelluloses) for the parent straw and $329 \pm 9$ for the residues. Holocelluloses were significantly more biodegradable in any of the delignified residues than in native wheat straw. In the attempt to evidence any significant correlation between the digestibility of the residues and their accessibility to enzymes, the specific methane production per mass of organic matter is reported in Fig. 4 as a function of surface area. The methane 
productivity was constant at $295 \pm 4 \mathrm{Ncm}^{3}{ }_{\mathrm{CH}} / \mathrm{g}_{\mathrm{OM}}$ for surface areas larger than $15 \%$, viz. for all the organosolv residues. This value was more than one and a half the value of native straw, $189 \mathrm{Ncm}^{3}{ }_{\mathrm{CH} 4} / \mathrm{g}_{\mathrm{OM}}$. In the graph of Fig. 3, it has been shown that pore volume and surface area steadily increased with the delignification level. Such trend clearly differs from the methanisation pattern shown in Fig. 4.

\section{Figure 4}

The plateau of methane productivity for the residues can be easily explained if the level of the plateau is taken into account. The maximum methane amount which can be developed by anaerobic carbohydrate digestion has been evaluated at $370 \mathrm{Ncm}^{3} \mathrm{~g}^{-1}$ (Frigon and Guiot, 2010). Under this assumption, the methanisation yield of the pulps is between 86 and $91 \%$. Such a high yield is probably the practical process maximum, which can already be obtained by the limited improvement of accessibility resulting from the less severe organosolv treatments. Further increases of pore volume and surface area did not improve the final methanisation yield, although it could be expected that they can improve the kinetics of bacterial digestion (Grethlein, 1985).

In order to evaluate the contribution of methanisation to the economics of the whole process, the amount of methane formed is reported in Fig. 5 per mass of parent straw used in the pulping treatment. Methanisation of the parent straw allowed the development of $190 \mathrm{Ncm}^{3} \mathrm{CH} 4$ per gram of initial straw. Instead, the methane production from the acid organosolv pulps was in the range between 84 and $146 \mathrm{Ncm}^{3} \mathrm{CH}_{4} / \mathrm{g}$ of initial DM. Indeed, the trend of methane production of Fig. 5 indicates that every pulping treatment decreases the amount of methane obtained per unit mass of parent 
straw, as the data include the digestibility per mass of the residue and the yield of pulping for each treatment. The trend can be easily explained by the yield data reported in Fig. 1. The increased severity of the acid treatment brought a significant dissolution of hemicellulose and cellulose fractions and decreased the amount of holocelluloses available for anaerobic digestion.

\section{Figure 5}

The amount of lignin and phenolics recovered in the catalytic organosolv process has been detailed by Constant et al. (2015) and increases with the severity of pulping, as reported in Fig. 5. The amount of recovered lignin and the market value of the products obtained with catalysts of different acid strength have been indicated as the main factors affecting the economic balance of the process. The production of methane from the residues is the valorisation of the byproduct of a process essentially aimed to the production of lignins with specific properties and the decrease of the amount of methane formed does not impair the contribution of the anaerobic digestion to the viability of the whole process.

No specific correlation between the crystallinity of the cellulose (Table 2) and the anaerobic biodegradabilities was found. This result is not surprising, when it is considered that virtual complete digestion of the holocellulose has been attained in all pulps. However, also in conditions of less complete digestion contradictory correlations were reported in the literature. The crystallinity degree of cellulose has been reported to influence the biodegradability of lignocellulosic biomass either negatively (Fan et al., 1980) or positively (Wyman, 1996) or without significant effects (Grethlein, 1985). The 
differences between these reports may arise from other factors, such as the size and volume of pores or the removal and modification of other components (lignin and hemicelluloses).

\section{Conclusions}

Lewis-acid catalysed ethanosolv treatments highly increased the anaerobic digestibility of straw biomass, both by a decrease of lignin fraction and the improved accessibility of polysaccharides through the porosity opened by the extraction of the lignin matrix. Pore volume and surface area of the pulping residue increased with the strength of the Lewis acid cation,in parallel with the extent of delignification and extraction of hemicelluloses. .

\section{Acknowledgements}

Sebastião Braz de la Faria Junior and Nicolas Beaufils are thanked for their participation to the project. The authors are grateful to the ANR Carnot Institute Chimie Balard and the INRA-CNRS GDR Biomatpro for financial support. The author would like to thank MENESR, ENSCM, CNRS and INRA for supporting this work.

\section{Appendix A. Supplementary data}

Supplementary data associated with this article are available online.

\section{References}

1. Arantes, V., Saddler, J.N., 2011. Cellulose accessibility limits the effectiveness of minimum cellulase loading on the efficient hydrolysis of pretreated lignocellulosic substrates. Biotechnol. Biofuels 4: 3. 
2. Barakat, A., de Vries, H., Rouau, X., 2013. Dry fractionation process as an important step in current and future lignocellulose biorefineries: a review.. Bioresource Technol. $134,362-73$.

3. Barakat, A., Chuetor, S., Monlau, F., Solhy, A., Rouau, X., 2014. Eco-friendly dry chemo-mechanical pretreatments of lignocellulosic biomass: Impact on energy and yield of the enzymatic hydrolysis. Appl. Energy. 113, 97-105.

4. Chang, S.S., Clair, B., Ruelle, J., Beauchene, J., Di Renzo, F., Quignard, F., Zhao, G.J., Yamamoto,Y., Gril, J., 2009. Mesoporosity as a new parameter for understanding tension stress generation in trees. J. Exp. Bot. 60, 3023-3030.

5. Constant, S., Basset, C., Dumas, C., Di Renzo, F., Robitzer, M.. Barakat, A., Quignard, F., 2015. Reactive organosolv lignin extraction from wheat straw: Influence of Lewis acid catalysts on structural and chemical properties of lignins. Ind. Crops Prod. $65,180-189$.

6. Dang, V.Q., Bhardwaj, N.K., Hoang, V., Nguyen, K.L., 2007. Determination of lignin content in high-yield kraft pulps using photoacoustic rapid scan Fourier transform infrared spectroscopy. Carbohyd. Polym. 68, 489-494.

7. Fan, L.T., Lee, Y.-H., Beardmore, D.H., 1980. Mechanism of the enzymatic hydrolysis of cellulose: Effects of major structural features of cellulose on enzymatic hydrolysis. Biotechnol. Bioeng. 22, 177-199.

8. Fang, Z. (ed.), 2013. Pretreatment techniques for biofuels and biorefineries. SpringerVerlag, Heidelberg.

9. Frigon, J.C., Guiot, S.R., 2010. Biomethane production from starch and lignocellulosic crops: a comparative review. Biofuel Bioprod. Bior. 4, 447-458. 
10. Grethlein, H.E., 1985. The Effect of Pore Size Distribution on the Rate of Enzymatic Hydrolysis of Cellulosic Substrates. Nat. Biotechnol. 3, 155-160.

11. Hayes, D.J., 2009. An examination of biorefining processes, catalysts and challenges. Catal. Today 145, 138-151.

12. Hendriks, A.T.W.M., Zeeman, G., 2009. Pretreatments to enhance the digestibility of lignocellulosic biomass. Biores. Technol.100, 10-18.

13. Huijgen, W.J.J., Smit, A.T., Reith, J.H., den Uil, H., 2011. Catalytic organosolv fractionation of willow wood and wheat straw as pretreatment for enzymatic cellulose hydrolysis. J. Chem. Technol. Biotechnol. 86, 1428-1438.

14. Jard, G., Jackowiak, D., Carrère, H., Delgenes, J.P., Torrijos, M., Steyer, J.P., Dumas, C., 2012. Batch and semi-continuous anaerobic digestion of Palmaria palmata. Comparison with Saccharina latissima and inhibition studies, Chem. Eng. J. 209, 513519.

15. Kim, Y., Yu, A., Han, M., Choi, G.W., Chung, B., 2010. Ethanosolv pretreatment of barley straw with iron(III) chloride for enzymatic saccharification. J. Chem. Technol. Biotechnol. 85, 1494-1498.

16. Kleinert, T., Tayenthal, K., 1932. Process of decomposing vegetable fibrous matter for the purpose of the simultaneous recovery both of the cellulose and of the incrusting ingredients. U.S. Pat. 1,856,567.

17. Lawter, J.M., Sun, R.C., Banks, W.B., 1996. Extraction and comparative characterization of ball-milled lignin LM, enzyme lignin LE and alkali lignin LA from wheat straw. Cellul. Chem. Technol. 30, 395-410.

18. Liu, R.G., Yu, H., Huang, Y., 2005. Structure and morphology of cellulose in wheat straw, Cellulose. 12, 25-34. 
19. Liu, L., Sun, J.S., Cai, C.Y., Wang, S.H., Pei,H.S., Zhang, J.S., 2009. Corn stover pretreatment by inorganic salts and its effects on hemicellulose and cellulose degradation. Bioresour. Technol. 100, 5865-5871.

20. Lopez-Linares, J.C., Romero, I., Moya, M., Cara, C., Ruiz, E., Castro, E., 2013. Pretreatment of olive tree biomass with $\mathrm{FeCl}_{3}$ prior enzymatic hydrolysis, Bioresour. Technol. 128, 180-187.

21. Lora, J.H., Glasser, W.G., 2002. Recent industrial applications of lignin: a sustainable alternative to nonrenewable materials. J. Polym. Environ. 10, 39-48.

22. Monlau, F., Barakat, A., Steyer, J.P., Carrere, H., 2012. Comparison of seven types of thermo-chemical pretreatments on the structural features and anaerobic digestion of sunflower stalks, Bioresour. Technol. 120, 241-247.

23. Monlau, F., Barakat, A., Trably, E., Dumas, C., Steyer, J.P., Carrere, H., 2013. Lignocellulosic materials into biohydrogen and biomethane: impact of structural features and pretreatment. Crit. Rev. Environ. Sci. Technol. 43, 260-322.

24. Motte, J.C., Escudié, R., Hamelin, J., Steyer, J.P., Bernet, N., Delgenes, J.P., Dumas, C., 2014. Substrate milling pretreatment as a key parameter for solid-state anaerobic digestion optimization. Biores. Technol.173, 185-192.

25. Pan, X., Arato, C., Gilkes, N., Gregg, D., Mabee, W., Pye, K., Xiao, Z., Zhang, X., Saddler, J.,2005. Biorefining of softwoods using ethanol organosolv pulping:

preliminary evaluation of process streams for manufacture of fuel-grade ethanol and coproducts. Biotechnol. Bioeng. 90, 473-481.

26. Renard, C.M.G.C., Lahaye, M., Mutter, M., Voragen, F.G.J., Thibault, J.F.,1997. Isolation and structural characterisation of rhamnogalacturonan oligomers generated by controlled acid hydrolysis of sugar-beet pulp. Carbohydr. Res. 305, 271-280. 
27. Rovio, S., Kallioinen, A., Tamminen, T., Hakola, M., Leskelä, M., Siika-aho, M., 2012. Catalysed alkaline oxidation as a wood fractionation technique. Bioresources 7 , 756-776.

28. Singh, S., Dutt, D., Tyagi, C.H., 2011. Complete characterization of wheat straw (triticum aestivium PBW-343 L. Emend. Fiori \& Paol.) - A renewable source of fibres for pulp and paper making. Bioresources. 6, 154-177.

29. Sun, R.C., Rowlands, P., Lawther, J.M., 2000. Rapid isolation and physic-chemical characterization of wheat straw lignins, Recent Res. Devel. Agr. Food Chem. 4, 1-26. 30. Sun, R.C., 2010. Cereal Straw as a Resource for Sustainable Biomaterials and Biofuels. Elsevier Science, Amsterdam, p. 192.

31. Wang, W., Yuan, T.Q., Cui, B.K., 2013. Fungal treatment followed by $\mathrm{FeCl}_{3}$ treatment to enhance enzymatic hydrolysis of poplar wood for high sugar yields. Biotechnol. Lett. 35, 2061-2067.

32. Wildschut, J., Smit, A.T., Reith, J.H., Huijgen, W.J.J., 2013. Ethanol-based organosolv fractionation of wheat straw for the production of lignin and enzymatically digestible cellulose. Bioresour. Technol. 135,) 58-66.

33. Wyman, C.,1996. Handbook on Bioethanol: Production and Utilization. CRC Press, Boca Raton (Fa.)

34. Yi, J., He, T., Jiang,Z.C., Li, J.M., Hu, C.W., 2013. AlCl 3 catalyzed conversion of hemicellulose in corn stover. Chinese J. Catal. 34, 2146-2152.

35. Yu, C.T., Chen, W.H., Men, L.C., Hwang, W.S., 2009. Microscopic structure features changes of rice straw treated by boiled acid solution. Ind. Crops Prod. 29, 308315. 


\section{Figure captions}

Fig. 1. Yields of cellulose (blue circles), hemicellulose (red squares) and lignin (green triangles) in the residue as a function of the hardness of the Lewis acid used in the organosolv treatment. Yields of the reference $\mathrm{H}_{2} \mathrm{SO}_{4}$ treatment are reported on the same scale on the right side.

Fig. 2. Mesopore size distributions from $\mathrm{N}_{2}$ adsorption isotherms at $77^{\circ} \mathrm{K}$ for parent wheat straw (1) and organosolv residues from treatments with $\mathrm{H}_{\mathrm{s}} \mathrm{SO}_{4}(2), \mathrm{FeCl}_{2}$ (3), $\mathrm{CuCl}_{2}(4), \mathrm{FeCl}_{3}(5), \mathrm{Ga}(\mathrm{OTf})_{3}(6), \mathrm{Sc}(\mathrm{OTf})_{3}(7)$.

Fig. 3. Surface area (lozenges, left $\mathrm{Y}$ axis) and pore volume (void squares, right $\mathrm{Y}$ axis) as a function of the fraction of extracted non-cellulosic matrix.

Fig. 4. Methane productivity per mass of organic matter as a function of surface area.

Fig. 5. Properties of pulps as a funtion of the mass loss in the pulping process. Methane productivity per mass of parent straw (blue circles, lefthand axis) and fraction of lignin and phenolics recovered (maroon squares, righthand axis). The curves display the trends. 
Table 1: Chemical composition of different WS pulping residues (pulp)

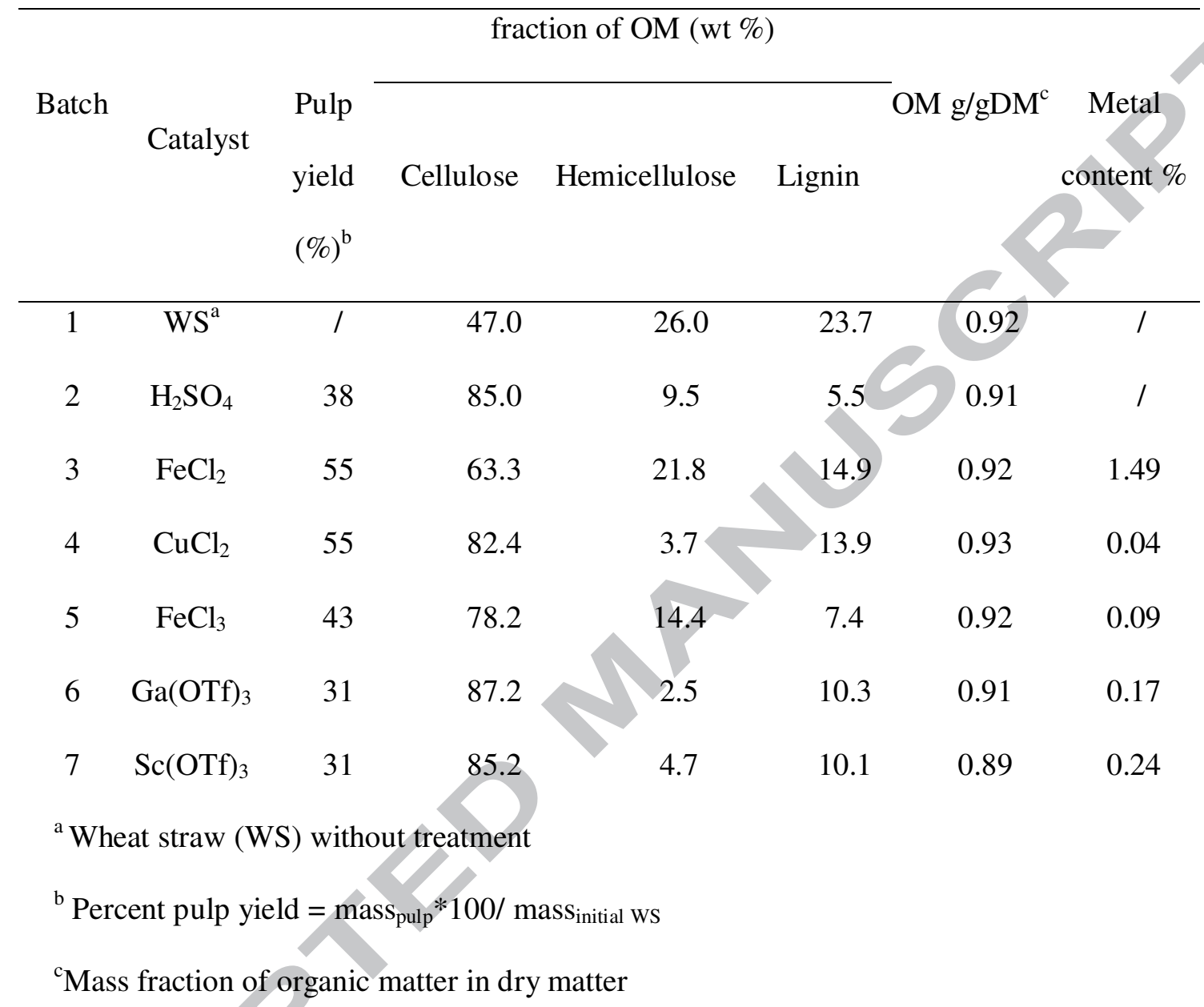


Table 2: Crystallinity index, spectroscopic indexes and textural properties.

\begin{tabular}{|c|c|c|c|c|c|c|c|}
\hline \multirow{2}{*}{ Batch } & \multirow{2}{*}{ Catalyst } & \multirow{2}{*}{$\begin{array}{l}\text { Crystallinity } \\
\text { Index }(\%)\end{array}$} & \multirow{2}{*}{$\begin{array}{l}\text { H } 1515 \text { / } \\
\text { H } 1430^{\mathrm{a}}\end{array}$} & \multicolumn{4}{|c|}{ H 1515 / Surface area Pore volume Pore diameter } \\
\hline & & & & $\mathrm{H} 1317^{\mathrm{a}}$ & $\left(\mathrm{m}^{2} \mathrm{~g}^{-1}\right)$ & $\left(\mathrm{cm}^{3} \mathrm{~g}^{-1}\right)$ & $(\mathrm{nm})$ \\
\hline 1 & Wheat straw & 54 & 0.50 & 0.50 & 1.5 & 0.002 & 5.7 \\
\hline 2 & $\mathrm{H}_{2} \mathrm{SO}_{4}$ & 47 & 0 & 0 & 14.0 & 0.018 & 5.0 \\
\hline 3 & $\mathrm{FeCl}_{2}$ & 48 & 0.33 & 0.25 & 5.3 & 0.009 & 6.5 \\
\hline 4 & $\mathrm{CuCl}_{2}$ & 46 & 0.33 & 0.25 & 11.1 & 0.015 & 5.4 \\
\hline 5 & $\mathrm{FeCl}_{3}$ & 58 & 0 & 0 & 104 & 0.015 & 5.6 \\
\hline 6 & $\mathrm{Ga}(\mathrm{OTf})_{3}$ & 57 & 0 & 0 & 20 & 0.032 & 4.5 \\
\hline 7 & $\mathrm{Sc}(\mathrm{OTf})_{3}$ & 50 & 0 & 0 & 16.3 & 0.021 & 5.1 \\
\hline
\end{tabular}




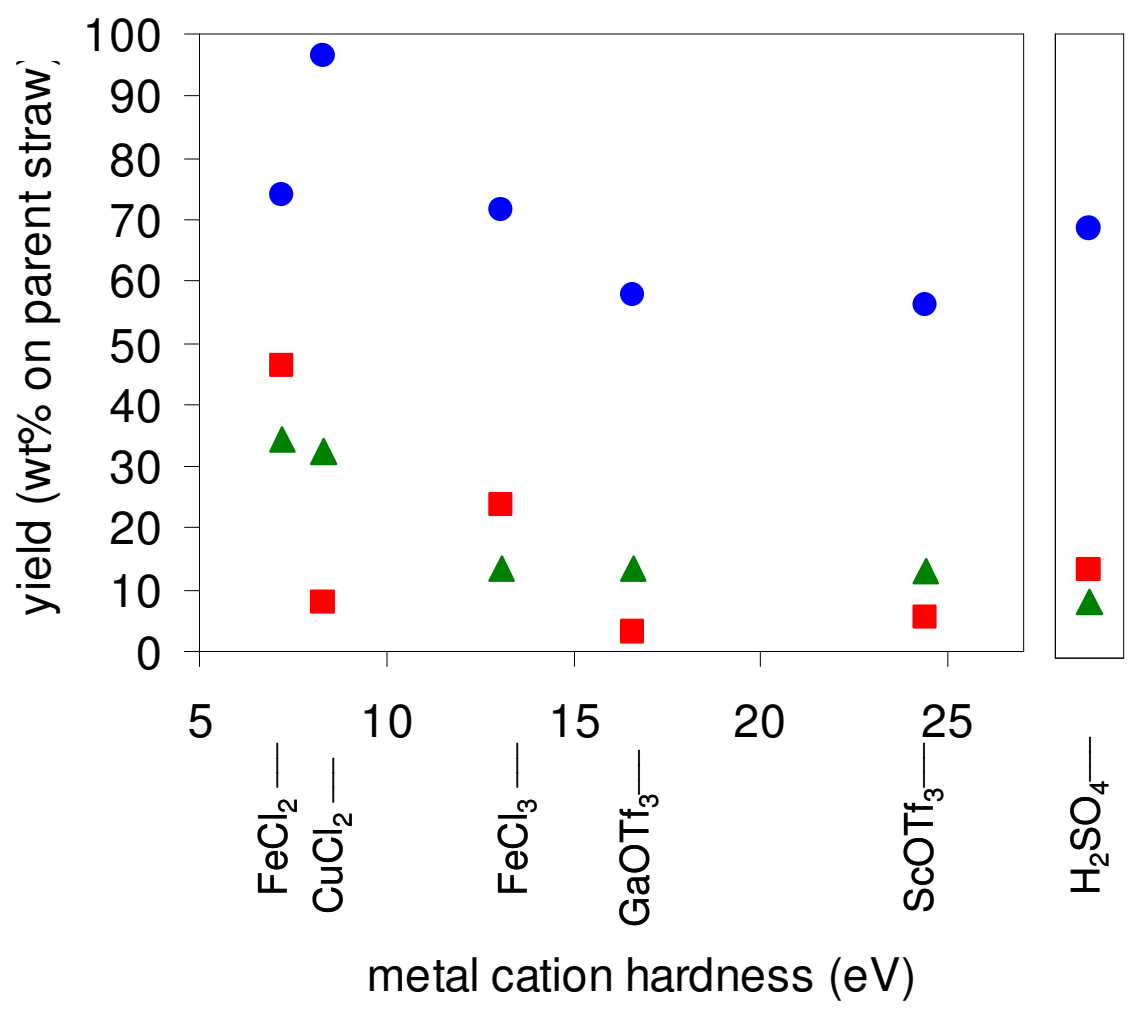

Fig. 1. Yields of cellulose (blue circles), hemicellulose (red squares) and lignin (green triangles) in the residue as a function of the hardness of the Lewis acid used in the organosolv treatment. Yields of the reference $\mathrm{H}_{2} \mathrm{SO}_{4}$ treatment are reported on the same scale on the right side. 


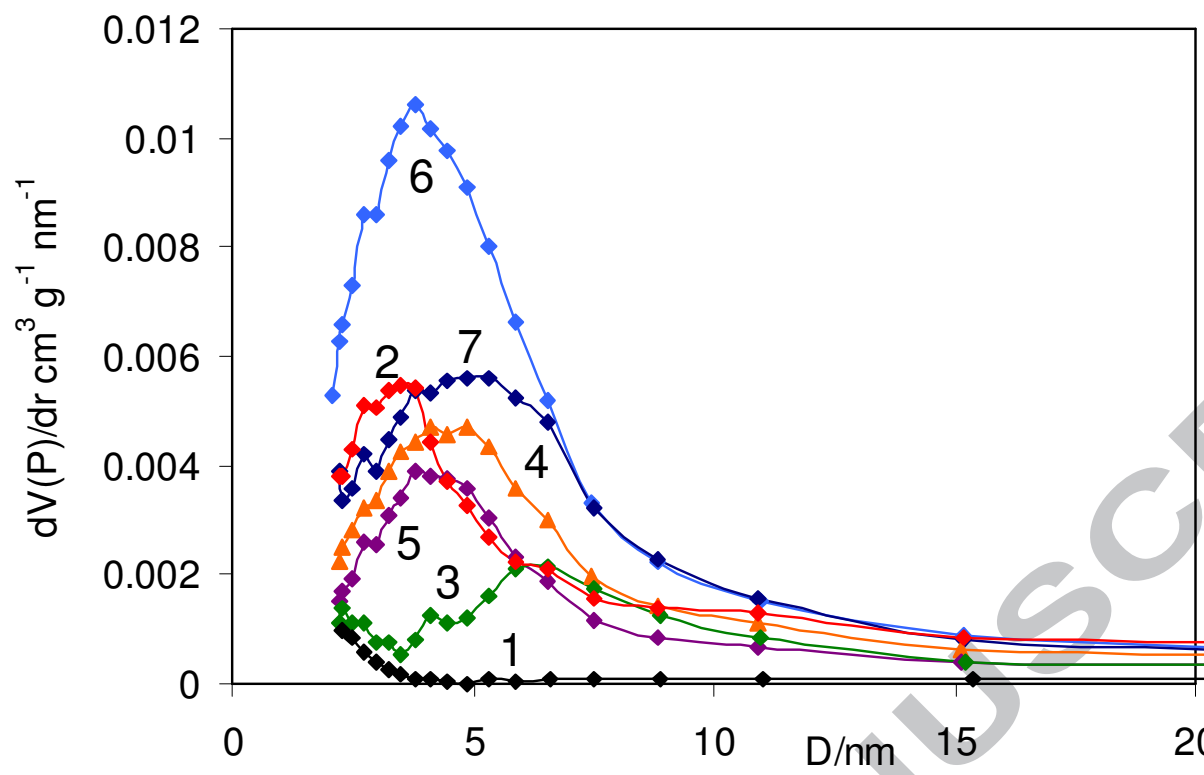

Fig. 2. Mesopore size distributions from $\mathrm{N}_{2}$ adsorption isotherms at $77^{\circ} \mathrm{K}$ for parent wheat straw (1) and organosolv residues from treatments with $\mathrm{H}_{\mathrm{s}} \mathrm{SO}_{4}(2), \mathrm{FeCl}_{2}$ (3), $\mathrm{CuCl}_{2}(4), \mathrm{FeCl}_{3}(5), \mathrm{Ga}(\mathrm{OTf})_{3}(6), \mathrm{Sc}(\mathrm{OTf})_{3}(7)$. 


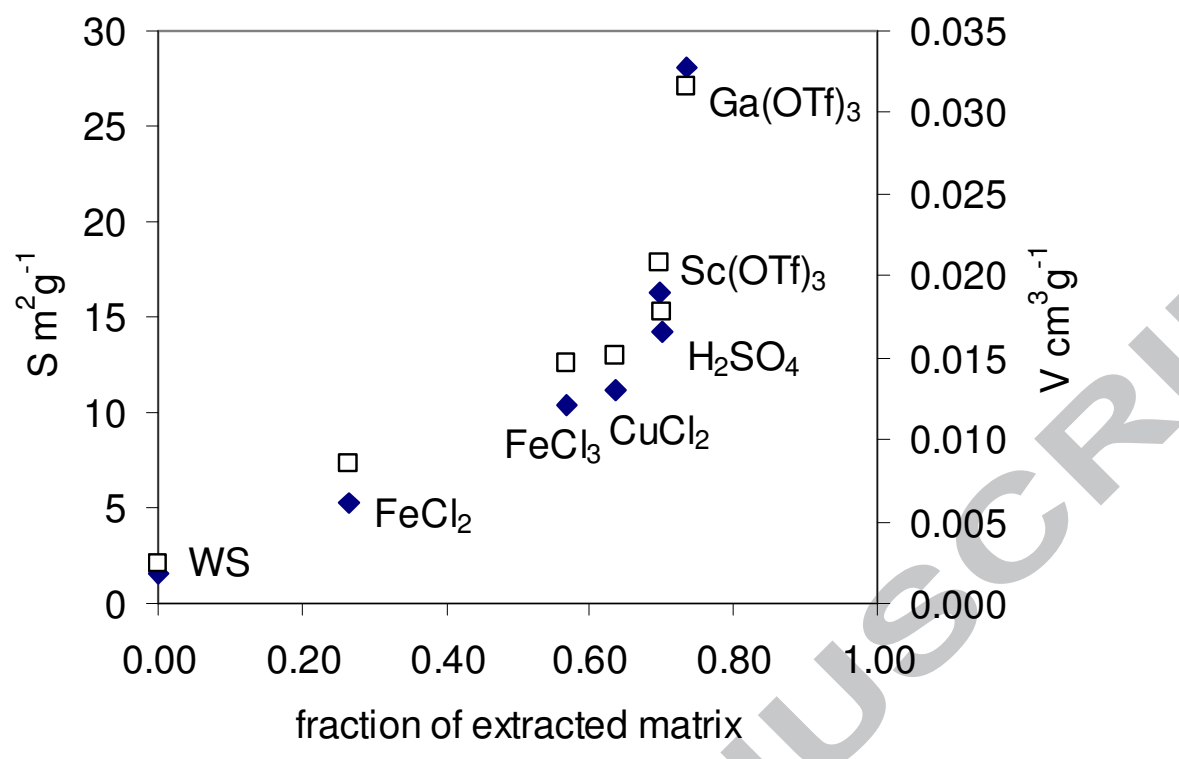

Fig. 3. Surface area (lozenges, left $\mathrm{Y}$ axis) and pore volume (void squares, right $\mathrm{Y}$ axis) as a function of the fraction of extracted non-cellulosic matrix. 


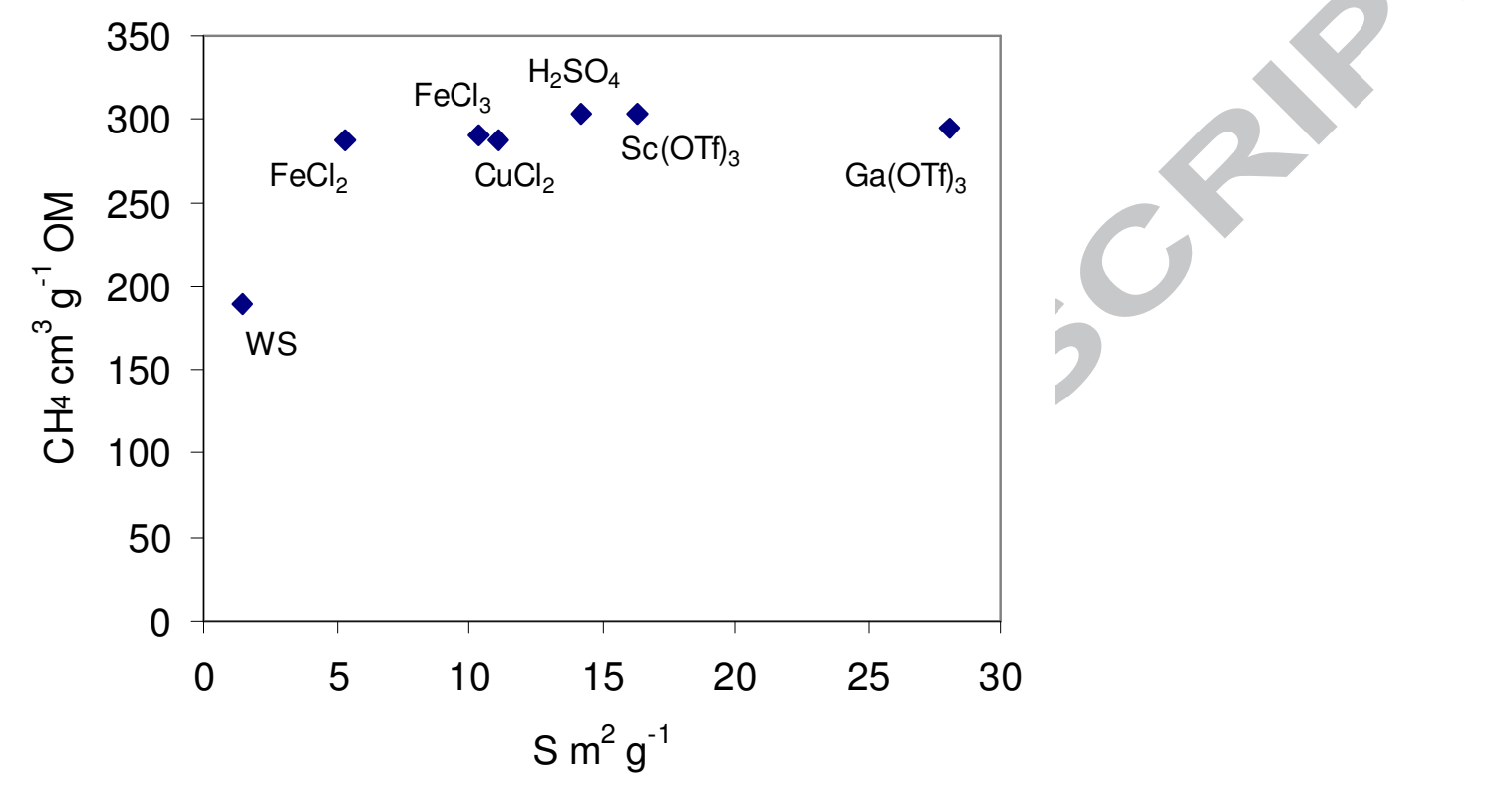

Fig. 4. Methane productivity per mass of organic matter as a function of surface area. 


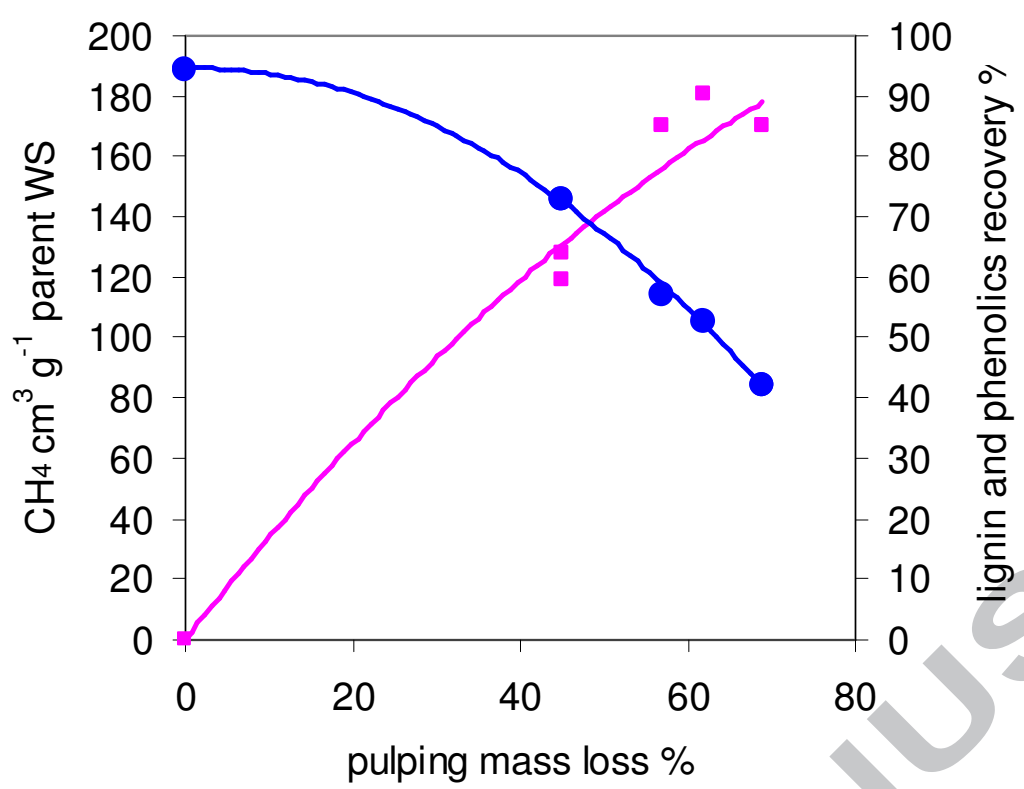

Fig. 5. Properties of pulps as a funtion of the mass loss in the pulping process. Methane productivity per mass of parent straw (blue circles, lefthand axis) and fraction of lignin and phenolics recovered (maroon squares, righthand axis). The curves display the trends. 
Methanisation allows effective valorisation of Lewis acid organosolv pulps

Porosity and surface area of pulp increase with lignin and hemicellulose removal

Methane evolution of $295 \mathrm{~L} / \mathrm{kg}_{\text {OM }}$ reached through improved accessibility

Residual Lewis acid catalysts do not impair holocellulose methanisation

Gallium triflate treatment leads to the best surface area of cellulosic residue 


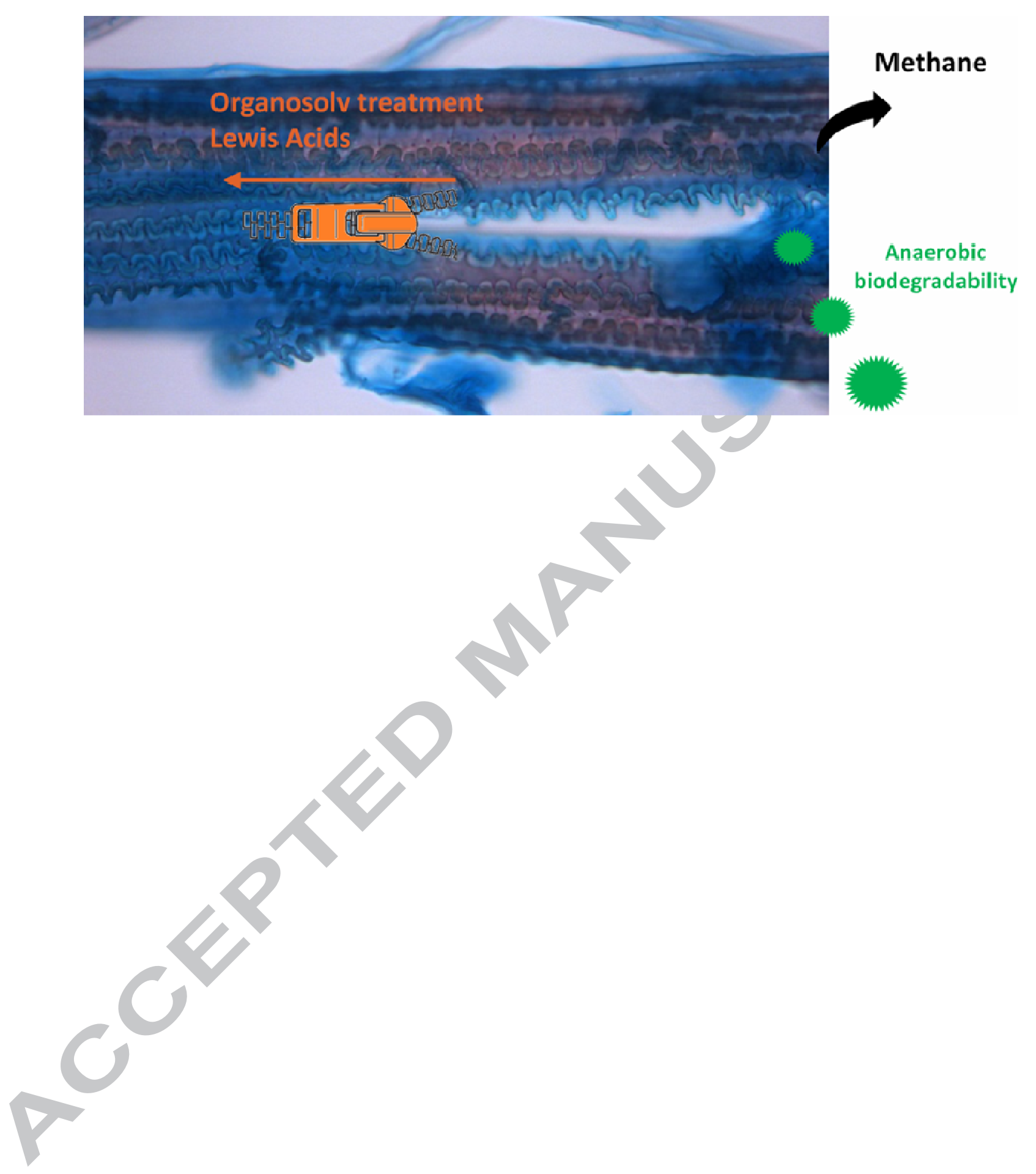

